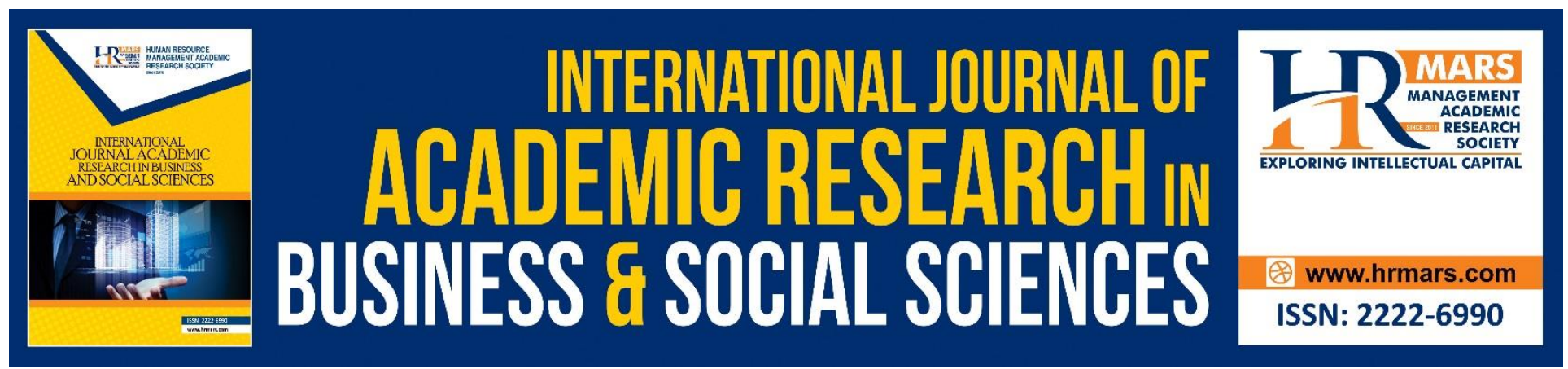

\title{
An Art Appreciation Approach on Analyzing Form and Content of Malay Culture of Symbols in Malaysian Painting Year 1980-1990
}

\author{
Liza Marziana Mohammad Noh, Nadzri Hj. Mohd Sharif, Sharmiza Abu \\ Hassan, Adam Wahida, Ohm Pattanachoti
}

To Link this Article: http://dx.doi.org/10.6007/IJARBSS/v10-i7/7457

DOI:10.6007/IJARBSS/v10-i7/7457

Received: 06 April 2020, Revised: 09 May 2020, Accepted: 29 June 2020

Published Online: 30 July 2020

In-Text Citation: (Noh et al., 2020)

To Cite this Article: Noh, L. M. M., Sharif, N. H. M., Hassan, S. A., Wahida, A., \& Pattanachoti, O. (2020). An Art Appreciation Approach on Analysing Form and Content of Malay Culture of Symbols in Malaysian Painting Year 1980-1990. International Journal of Academic Research in Business and Social Sciences, 10(7), 553-558.

Copyright: (C) 2020 The Author(s)

Published by Human Resource Management Academic Research Society (www.hrmars.com)

This article is published under the Creative Commons Attribution (CC BY 4.0) license. Anyone may reproduce, distribute, translate and create derivative works of this article (for both commercial and non-commercial purposes), subject to full attribution to the original publication and authors. The full terms of this license may be seen

at: http://creativecommons.org/licences/by/4.0/legalcode

Vol. 10, No. 7, 2020, Pg. 553 - 558

http://hrmars.com/index.php/pages/detail/IJARBSS

JOURNAL HOMEPAGE

Full Terms \& Conditions of access and use can be found at http://hrmars.com/index.php/pages/detail/publication-ethics 


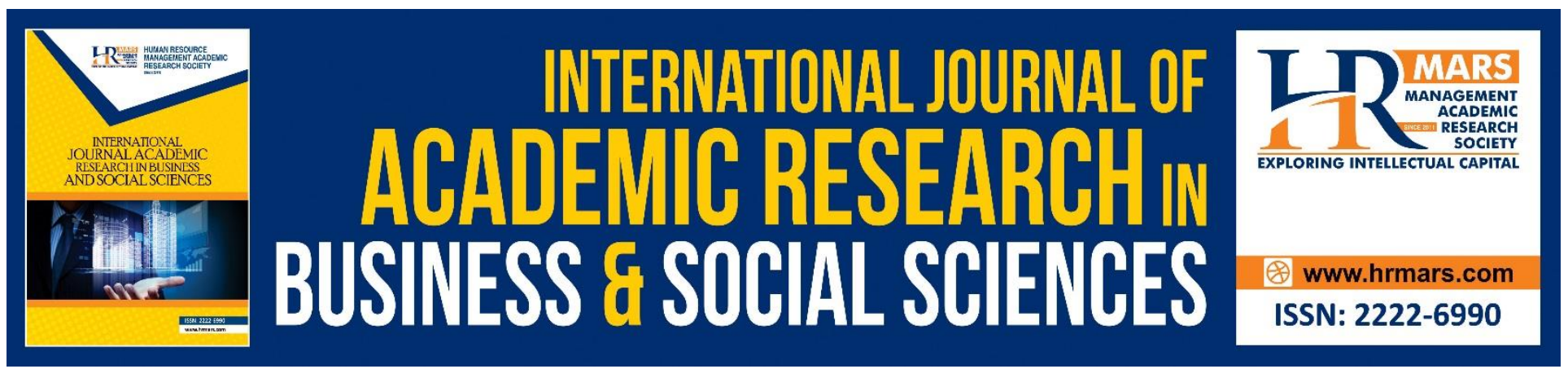

\title{
An Art Appreciation Approach on Analysing Form and Content of Malay Culture of Symbols in Malaysian Painting Year 1980-1990
}

\author{
${ }^{1}$ Liza Marziana Mohammad Noh, ${ }^{1}$ Nadzri Hj. Mohd Sharif, Sharmiza \\ Abu Hassan, ${ }^{2}$ Adam Wahida, ${ }^{3} \mathrm{Ohm}$ Pattanachoti \\ ${ }^{1}$ Faculty of Art and Design, Universitl Teknologi MARA, Melaka, Malaysia, ${ }^{2}$ Art Education \\ Department, Universitas Sebelas Maret, Surakarta, Indonesia, ${ }^{3}$ School of Social Science, Chiang Rai \\ Rajabhat University, Thailand \\ Email: lizamarziana@ymail.com
}

\begin{abstract}
To evaluate paintings, the beauty of it is not the central focus of study but more of the elements that lead to the creation of the beauty. The subject, the form and its meaning, are three basic characteristics in paintings that need to be studied. The three are inter-related and are inseparable because it is from them that a symbol is formed. That is how an artistic symbol contains the ideas or intentions of the painter. An artist is the creature of the symbol who translates his symbols through the form that carries a certain meaning. Thus, to study the form and meaning of the symbol of the Malay culture in paintings, the art appreciation approach has been adopted in this study. Four paintings dated back to the 1980s and the 1990s have been identified using Malay cultural symbols represented in both decorative and representative forms. The outcome of this study suggests that symbols such as Malay textile motives like pulikat, batik, silver metal floral motif and architecture as well as Malay interior decorations are the painters' selections. This study is significant to elevate the symbol of Malay culture as an identity of paintings and to sustain the traditional culture, for the reason that today, young artists are inclined to choose universal symbols more than they would traditional culture symbols.
\end{abstract}

Keywords: Art Appreciation, Form, Content, Painting, Malay Cultural, Symbol.

\section{Introduction}

Art is a human phenomenon. Human creates art to understand life or to communicate ideas with other humans. As stated by Lazzare et. al (2008) that "Art is primarily a visual medium that is used to express ideas about human experience and the world around us". Therefore, a feeling is a dominant factor for human beings other than the importance of observation and experience in giving life to the purpose of artistry. Art serves to be a translation of symbols that is included in the stage of expression of feelings. According Tjep (2000) human thinks, feels and acts in symbolic expressions. Every symbol expressed has its own function and the symbol contains some beliefs that normally serve as the 
INTERNATIONAL JOURNAL OF ACADEMIC RESEARCH IN BUSINESS AND SOCIAL SCIENCES

Vol. 10, No. 7, July, 2020, E-ISSN: 2222-6990 @ 2020 HRMARS

substance from religion, cognitive symbols forming knowledge, moral assessment symbols, expression of feelings or expressive symbols. All have been expressed on the basis of human life in the context of culture. Therefore, an artist would not be able to escape from connecting the gist of his artistry with any matters related to culture. As a bio-cultural creature, an artist would deliver his intention and desire generated from human soul, channeled through human streams of thoughts and practice, through art. Artists like painters, sculptors, printmaker even designers consistently try to enhance their sensibility and perception towards the dynamic of his own societal culture as the questions are very close to them. Other than that, apart from being known as a bio-cultural creature, an artist is also a creature that plays with symbols, where he translates the cultural symbols to express the cultural values that have been very much part of his life. The creation of the Malay cultural symbols is the painter's sensibility towards the Malay culture. The inclination towards the search for nation's artistic identity in the 1970s in the local visual arts has raised awareness among the painters to explore more into the Malay origins and its culture. This stems from the National Cultural Congress held to create national culture following the racial riot that took place in 1969. Consequentially, there arose various forms and meanings of the Malay culture translated by the painters actively back in the 1980 s and the 1990s. Thus, to study these symbols, the current work will adopt the method of art appreciation when detecting the symbols.

\section{Literature Review}

According to Ali (1989), in his book Seni dan Seniman: Esei-esei Seni Halus, it explains that arts appreciation is a practice that necessitates full involvement of the visual and touch sensory. When we appreciate an artistic object actively, then we will involve the use of language. Language is used either verbally, or in writing, thus the artistic object in itself is a language, or a visual language while the speaker is the artist, the tool is the arts object containing information and the recipient would be the observer. According to Ofuafo (2013) symbols could be defined as "objects, acts, relationship or linguistic formations that stand for a multiplicity of meaning". This definition indicates that there are different symbolic forms and that it is possible for one symbolic form to be given several interpretations, and these interpretations could thrive at different levels, depending on the level of the interpreter's consciousness and intelligence. Thus what a particular object symbolizes for people " $A$ " at time " $A$ " may be different from that of " $B$ ", and vice versa.

\section{Problem Statement}

This study is done to examine Malay cultural symbols in paintings. To detect this, the method of art appreciation is used according to the manner and views by Ragan (2000) dividing it into three basic characteristics namely subject, form and meaning. Ocvirk (2009) also stress on the approach of the form, content and meaning in analyzing works of art. They explain that the component of the subject (reference materials), form and meaning are complementary to the work in question. The approach adopted by Ragan (2000) is used to look closely into the subject by way of understanding the paintings deeply through four main aspects namely descriptions on the work itself, analysis on the images, the meaning interpretations and the assessment of the work. According to Ahmadrashidi (2006), in the aspect of identifying the subject, the analyst must identify and be able to make simple descriptions on the work, covering issues like the form of the work, the type of work, materials used, the subject, image(s) as well as the work size. According to Ahmadrashidi (2006) in the aspect of work analysis, an analyst should make a formal analysis and see how the work can be created. This encompasses the question of rearrangement or lay-out of the images displayed and how it will be an interesting 
INTERNATIONAL JOURNAL OF ACADEMIC RESEARCH IN BUSINESS AND SOCIAL SCIENCES Vol. 10, No. 7, July, 2020, E-ISSN: 2222-6990 @ 2020 HRMARS

work of art. The use of visual elements like the form, the line colour, the weaving and so on will be placed in the analysis as well. The advantage of this approach is as elaborated by Carol (1999) where it is said to be able to find the hidden meaning contained in the work of art. Important questions will be answered through a systematic process. As you go through the step of description and analysis, you will collect facts and clues. When you get to the interpretation, you will make guesses about what message you think the artwork is communicating. Finally during judgement, you will make your own decisions about the artistic merit of the work.

\section{Procedure and Methodology}

In finding the answer to the question, the researchers have chosen paintings of the $80 \mathrm{~s}$ and the $90 \mathrm{~s}$. Both decades were decades that are considered active in terms of the creation of the Malay cultural symbols. Based on the researchers' observation, it is found that the Malay cultural symbols like the Malay traditional arts are prioritised. 4 works from 4 painters are selected by the researcher to be analysed. The study that has been done on these works is based on the appreciation technique proposed by Ragan (2000). Among the aspects that have been analysed are as follows:
a. Subject
b. Form
c. Meaning
d. Material and Technique

\section{Findings}

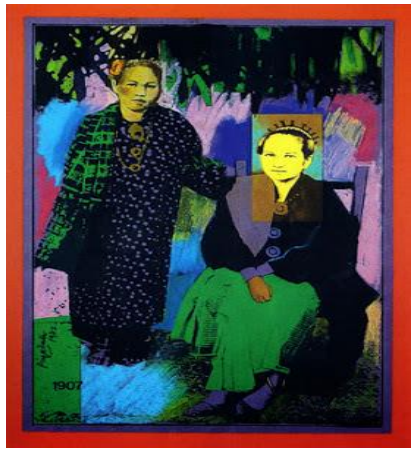

Art Appreciation

[1] Artist: Redza Piyadasa

Title: Dua Orang Wanita Melayu

(Two Malay Women)

Year: 1984

Media: Printmaking

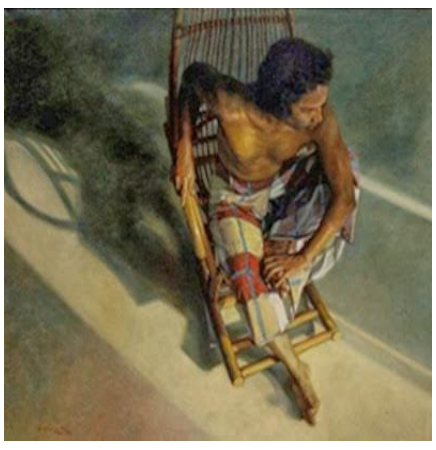

Art Appreciation

[2] Artist: Amron Omar

Title: Identiti Melayu

(Malay Identity)

Year: 1982

Media: Oil Paint 


\section{Subject:}

Figure of women wearing long kebaya, with veils and with head and body accessories

\section{Form:}

Figures standing and sitting. The use of contrasting colour

\section{Meaning:}

Highlighting Malay traditional costume

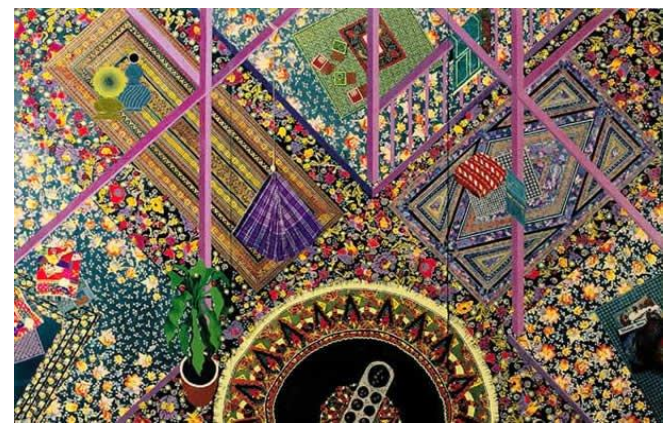

Art Appreciation

[3] Artist: Mastura Abdul Rahman

Title: House of Flowers, House of Harmony

Year: 1984

Media: Mixed media

\section{Subject:}

The figure of a man sitting. Not clothed and wearing a pulikat.

\section{Form:}

The position of the figure is balanced with his shadow. The use of dramatic colours and monochrome colours

\section{Meaning:}

An assertion of a Malay identity in terms of his skin colour and appearance. His wearing pulikat depicts a Malay costume. The object of a chair or a rattan 'lazy chair' depicts a Malay product.

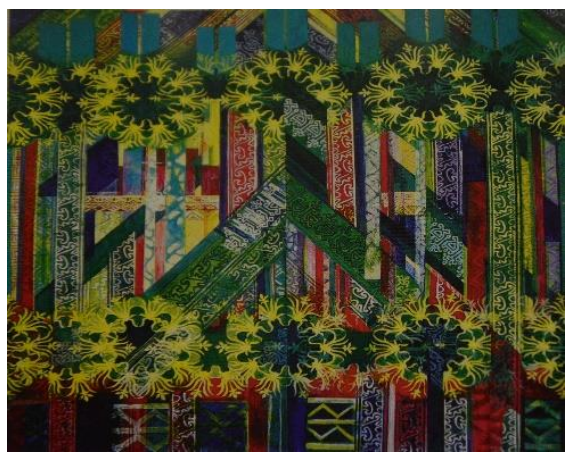

Art Appreciation

[4] Artist:Fatimah Chik

Title : Gunung

Year: 1987

Media: Mixed edia

\section{Subject:}

Floral motif from metal silver products, pucuk rebung (chevron) and awan larat.

\section{Form:}

Arranged like a landscape through the motif done in repetition. In the middle, there is a shape of chevron representing the form of mountains. Colour-wise, it uses earth colours like monochrome green.

\section{Meaning:}

Highlighting a mystical concept, on the mountain shape, and this portrays spiritual 
power. For another perspective, the triangle concept means hope and achievement.

\section{Conclusion}

Based on the observation, it is found that all the symbols created share the theme of Malay culture. Most of the symbols are Malay artistic symbols that are formed representatively and decoratively. Traditional arts symbols are stressed to connect the symbols with the Malay culture. Among them include Malay women traditional clothes, chevron, Malay craft products like clay, pulikat fabrics, congkak and architecture. There are also Islamic geometrical motifs like the praying mat, also the Verse of Yassin with an Islamic identity. Examining the whole of the work, most of the meaning of the work discreetly relates the aspect of tawheed of an artist towards his creator other than giving out messages on Malay femininity and culture. Although the images comprise of traditional arts symbols, the association of meaning that revolves around religious, femininity and cultural issues have successfully been depicted in a symbolic manner. This indicates that the symbolism behaviour is present in our local artists, when they deliver their messages and create symbols, each of which has its own distinctive function. As explained by Tjep (2000) the work that the human creates is not without its purpose. In other words, everything in the universe is touched and worked on, by human where it is given a new form that contains a certain value, demonstrating the meaning and notion of the creator. It serves as the symbols to the cultural scope.

\section{References}

Ali, Z. (1989). Seni dan seniman. Ese-esei seni halus. Kuala Lumpur: Dewan Bahasa dan Pustaka. Carrol, N. (1999). Philosophy of Art: A contemporary introduction. London: Routledge. Hasan, A. (2006). Seni lukis dan idea. Shah Alam: Universiti Teknologi MARA.

Lazzare, M., \& Schlesier, D. (2008). Exploring Art: A Global, Thematic Approach. 3rd. Edition. USA: Thomas Learning, Inc.

Ocvirk, R. E., Stinson, W. P. R., Bone, R., \& Clayton, D. L. (2009). Art fundamentals: Theory and practise. 11th Edition. New York: McGraw-Hill.

Ofuafo, J. P. U. (2013). Art Symbols as Means of Communication Religious Concepts in URHOBO Traditional Society. J. Inter. Soc. Sc, Vol 6, 392-397.

Ragan, R. (2000). Arttalk. California: Glencoe/McGraw Hill.

Rohidi, T. T. R. (2000). Kesenian. Dalam pendekatan kebudayaan. Bandung: ACCENT Graphic. Communication. 